\title{
Komparasi Penjatuhan Tindakan Rehabilitasi Menurut Undang-Undang Nomor 35 Tahun 2009 Tentang Narkotika (Studi Kasus Putusan Nomor 375/Pid.Sus/2015/PN.Jkt.Sel., Putusan Nomor 191/Pid.Sus/2015/PN.Jkt.Sel., dan Putusan Nomor 436/Pid.Sus/2015/PN.Jkt.Sel.
}

\author{
Alia Nabila \\ (Mahasiswa Program S1 Fakultas Hukum Universitas Tarumanagara) \\ (E-mail: nabilalia1097@gmail.com)
}

\section{Dr. Mety Rahmawati, S.H., M.H.}

(Corresponding Author)

(Dosen Fakultas Hukum Universitas Tarumanagara. Meraih Sarjana Hukum pada Fakultas Hukum Universitas Trisakti, Magister Hukum pada Fakultas Hukum Universitas Tarumanagara, Doktor (Dr.) Doktor (Dr.) pada Fakultas Hukum Universitas Trisakti)

(E-mail: metyargo@gmail.com)

\begin{abstract}
Narcotics can cause changes in consciousness and cause dependence. Drug use is often needed. Regarding the Narcotics Law Number 35 of 2009 gave birth to an effort to cure the perpetrators of narcotics abuse, namely rehabilitation. Rehabilitation is a recovery effort so that a person can return to his previous state. However, not all cases of drug abuse can be sought for rehabilitation. In the case of perpetrators of narcotics abuse, rehabilitation has been sought as seen in the decision number 191/Pid.Sus/2015/PN.Jkt.Sel., while in the decision number 375/Pid.Sus/2015/PN.Jkt.Sel., and decision number 436/Pid.Sus/2015/PN.Jkt. Cells, narcotics abuse is not sought for rehabilitation and even given criminal sanctions. Act to Law No. 35 of 2009 concerning Narcotics against narcotics abusers if proven to abuse narcotics it is compulsory to undergo rehabilitation in accordance with the provisions of Article 127 Paragraph (1) of the Narcotics Law. And the three decisions in decision number 191/Pid.Sus/2015/PN.Jkt.Sel., Decision number 375/Pid.Sus/2015/PN.Jkt.Sel and decision number 436/Pid.Sus/2015/PN.Jkt.Sel., Was charged as a drug abuser.
\end{abstract}

Keywords: rehabilitation, difference in the resolution, drug abuse

\section{PENDAHULUAN}


A. Latar Belakang

436/Pid.Sus/2015/PN.Jkt.Sel.

INDONESIA merupakan suatu negara yang memiliki berbagai macam golongan masyarakat, sehingga diperlukan sebuah pranata yang mengatur tentang kehidupan masyarakat. Pranata tumbuh ditengah masyarakat biasa disebut dengan norma, salah satu dari norma tersebut adalah norma hukum. Hukum itu terdiri dari perbuatan macam bentuk salah satunya adalah hukum pidana. Hukum pidana dapat diartikan "suatu bagian yang merupakan keseluruhan dari hukum yang berlaku di dalam suatu Negara, dengan mengadakan dasar-dasar dan pengaturan untuk": ${ }^{1)}$

a. "Menentukan perbuatan apa-apa saja yang boleh dilakukan dan tidak boleh dilakukan, jika yang tidak boleh dilakukan tsb justru dilakukan akan mendapatkan ancaman atau sanksi berupa pidana tertentu;

b. Menentukan apa-apa saja kepada mereka yang melanggar larangan tsb harus dikenakan atau bahkan dijatuhi suatu hukuman pidana sebagaimana yang telah diancamkan tsb;

c. Menentukan dengan cara seperti apa penerapan pidana tsb dapat dilaksanakan apabila seseorang yang disangka sudah melanggar larangan tsb."

Upaya dalam menegakkan suatu hukum dan suatu keadilan dengan berdasarkan kepada "Pancasila dan Undang-Undang Dasar Negara Kesatuan Republik Indonesia 1945" dengan menjunjung tinggi Hak Asasi Manusia serta menjamin segala warga negara bersamaan kedudukannya di dalam hukum dan pemerintahan dan wajib menjunjung hukum dan pemerintahn tanpa terkecuali. Hukum merupakan suatu hak yang mutlak yang dimiliki oleh suatu negara apapun sistem yang digunakan negara tersebut, Seperti yang tercantum dalam Pasal 1 Ayat (3) Undang-Undang Dasar Republik Indonesia Tahun 1945 yang menyatakan bahwa "Negara Indonesia berdasar atas hukum, tidak berdasarkan atas kekuasaan belaka.”

Tindak pidana ialah suatu perbuatan yang dilakukan oleh manusia yang mana perbuatan tsb dapat melanggar apa yang dilarang atau diperintahkan oleh Undang-

\footnotetext{
${ }^{1)}$ Moeljatno, Asas-Asas Hukum Pidana, Edisi Revisi, (Jakarta: Rineka Cipta,2008), hal. 1
} 
Undang yang harus di pertanggung jawabkan dengan diberikan sanksi berupa pidana.

Dalam hal ini tindak pidana yang selalu berulang kali dilakukan oleh seseorang atau beberapa kelompok yaitu tindak pidana narkotika. Masalah tindak pidana narkotika saat ini telah merasuki semua elemen bangsa, mulai dari anak-anak hingga orang dewasa, aparat penegak hukum bahkan sampai orang dari kalangan bawah juga tidak steril dari pemakaian narkotika, sehingga upaya pemberantasannya perlu sangat dengan ekstra, mengingat bahwa narkotika adalah musuh bersama suatu Negara atau Bangsa. Adapun dampak yang ditimbulkan dari bahaya narkotika seperti:

Dampak Bahayanya Narkotika Bagi Penyalahgunaan Narkotika, yang ditimbulkan seperti dampak fisik yaitu:

a. "Gangguan yang terjadi dalam fungsi saraf (neorologis) yang akan ditimbulkan misalnya: mengalami kejang-kejang, berhalusinasi, hilangnya kesadaran, malfungsi pada sistem saraf.

b. Gangguan pada jantung yang mengakibatkan infeksi dan gangguan pembuluh darah (kardiovaskuler)."

Dampak psikologis yang ditimbulkan seperti: Berfikir tidak normal, selalu berperasaan cemas, tubuh membutuhkan jumlah tertentu untuk mendapatkan keinginannya, mengalami ketergantungan/selalu membutuhkan obat agar mendapatkan ketenangan.

Lalu yang terakhir pada dampak sosial yang ditimbulkan berupa: tidak memiliki jiwa sosial terhadap masyarakat, selalu mengurung diri terhadap banyak orang, terganggunya masyarakat sekitar karena adanya penyalahguna narkotika.

Narkotika ini berasal dari bahasa yunani, yaitu "narkoun" yang berarti membuat seseorang merasa lumpuh atau mati rasa. Dalam "UU Nomor 35 Tahun 2009 Tentang Narkotika Pasal 1 Ayat (1)" menyatakan bahwa "narkotika merupakan dzat atau obat yang dapat mengakibatkan terjadinya penurunan atau bahkan terjadi suatu perubahan 
kesadaran, hilangnya rasa, bias mengurangi sampai menghilangkan rasa nyeri, dan dapat menimbulkan ketergantungan.”

Masalah terkait dengan penyalahguna narkotika yang telah terjadi dalam masyarakat membutuhkan perhatian dan penanganan secara khusus oleh Indonesia bahkan sampai dunia Internasional. Masalah tsb menjadi sangat penting mengingat bahwa narkotika tersebut adalah suatu zat yang berbahaya yang dapat merusak fisik dan mental seseorang apabila penggunaan narkotika tersebut tidak diawasi dan tanpa resep dokter. ${ }^{2)}$ Korban-korban dari penyalahgunaan narkotika sebagian besar dari generasi muda yang berarti dampak negatif akibat dari penyalahguna narkotika tersebut sangat serius, karena secara langsung merusak generasi muda harapan bangsa yang akan datang. Antara negara-negara ASEAN konon di Indonesia sebagai penegak hukum yang paling "berbaik hati” terhadap para pelaku penyalahgunaan narkotika. ${ }^{3)}$

Dalam dunia kedokteran, Narkotika dapat dipergunakan untuk membius seorang pasien sebelum dilakukanna operasi, hal ini dilakukan karena di dalam Narkotika terdapat zat yang dapat mempengaruhi perasaan, pikiran, dan kesadaran pasien. ${ }^{4}$ Oleh karena itu, agar penggunaan Narkotika tersebut dapat memberikan manfaat bagi kehidupan manusia maka peredarannya harus diawasi secara ketat dan harus mendapatkan surat keterangan dari kedokteran dan dibawah pengawasan dokter khusus dalam hal penggunaannya. Awal kemerdekaan, obat bius digunakan oleh Indonesia untk mengatur masalh narkotika. Permasalahan narkotika semakin meluas di dalam masyarakat sehingga membutuhkan penanganan khusus. Karena itu, Pemerintah dan Dewan Perwakilan Rakyat memandang perlu segera dibentuk undang-undang (UU) agar dapt menjangkau setiap bentuk penyalahgunaan

\footnotetext{
2) Kusno Adi, Kebijakan Kriminal Dalam Penanggulangan Tindak Pidana Narkotika Oleh Anak, Cetakan Ke-1, (Malang: UMM Press, 2009), hal. 30

3) Yuwono Prianto, "Penyalahgunaan Narkoba dan Upaya Penegakan Hukumnya”, Jurnal Era Hukum Ilmiah Ilmu Hukum, Edisi No. 1 Tahun 2015, hal. 58.

4) Frans Hendra Winarta, Bantuan Hukum: Suatu Hak Asasi Manusia Bukan Belas Kasihan, (Jakarta:

PT. Elex Media Komputindo, 2000), hal. 100.
} 
narkotika. ${ }^{5)}$ Maka dibentuklah suatu "Undang-Undang Nomor 22 pada tahun 1997 tentang Narkotika dan juga Undang-Undang tentang Psikotropika dan kemudian diubah menjadi Undang-Undang Narkotika Nomor 35 tahun 2009 yang mencabut Undang-Undang Nomor 22 tahun 1997" serta mencabut Golongan I \& II Psikotropika masuk kedalam daftar Golongan I Narkotika.

Menurut "Undang-Undang Narkotika", agar diharapkan untuk memberantas penyalahguna narkotika di Indonesia, apapun banyak dari pemanfaatan narkotika, terkecuali sbg tujuan dari penelitian (ilmu pengetahuan) dan juga kesehatan, maka dari itu apapun jenis penyimpangan dari narkotika tsb dapat dikategorikan sbg suatu tindak pidana kejahatan. Namun sesudah berlakunya undang-undang narkotika tsb, tindak pidana penyalahguna narkotika belum dapat diberantas secara maksimal dan seharusnya hal tsb merupakan tugas dan tanggung jawab dari semua pihak termasuk masyarakat. ${ }^{6)}$ Pengertian Penyalahguna menurut Undang-Undang Narkotika adalah "seseorang yang tanpa hak dan/atau melawan hukum telah menggunakan narkotika". ${ }^{7)}$ Sedangkan Korban Penyalahguna Narkotika adalah adalah seseorang yang tidak sengaja menggunakan Narkotika karena dibujuk, diperdaya atau bahkan diancam untuk mengkonsumsi Narkotika. ${ }^{8)}$

Sementara itu, jika di lihat dari fakta empirisnya dalam bidang pemidanaan secara umum masih menganut suatu konsep yang hanya memberikan suatu penghukuman terhadap pelaku tindak pidana dalam lembaga permasyarakatan saja, dengan demikian maka suatu tindak pidana kejahatan hanya dapat berenti sesaat dan pelaku tindak pidana dapat mengulangi suatu tindak pidana tsb. Hal tersebut juga berkaitan

\footnotetext{
5) Anang Iskandar, Jalan Lurus Penangan Penyalahguna Narkotika Dalam Konstruksi Hukum Positif, (Karawang: Viva Tanpas, 2015), hal.7.

${ }^{6)}$ Moh. Taufik Makaro, dkk, Tindak Pidana Narkoba, (Bogor: Penerbit Ghalia Indonesia,2005), hal.7

7) Indonesia, Undang-Undang Nomor 35 Tahun 2009 tentang Narkotika (Lembaran Negara Republik Indonesia Tahun 2009 Nomor 143, Tambahan Negara Lembaran Negara Republik Indonesia Tahun 2009 Nomor 5062), Pasal 1 Ayat 15.

${ }^{8)}$ Indonesia, Peraturan Pemerintah Noor 25 Tahun 2011 tentang Pelaksanaan Wajib Lapor Pecandu Narkotika, (Lembaran Negara Republik Indonesia Tahun 2011 Nomor 46, Tambahan Negara Lembaran Negara Republik Indonesia Tahun 2011 Nomor 5211), Pasal 1 Ayat 4.
} 
dengan pemidanaan yang terjadi terhadap penyalahguna Narkotika yaitu seharusnya dengan dilakukannya upaya rehabilitasi medis dan rehabilitasi sosial.

Undang-Undang Narkotika tidak menyebutkan pengertian rehabilitasi secara jelas, yang terdapat disana adalah pengertian rehabilitasi medis dan sosial. Rehabilitasi medis adalah suatu tindakan untk membebaskan pecandu dari ketergantungan narkotika dengan pengobatan secara terpadu. Sedangkan rehabilitasi sosial adalah suatu tindakan berupa kegiatan yang dilakukan secara terpadu, baik fisik, mental maupun jiwa sosialnya, agar pecandu narkotika dapat kembali melaksanakan fungsi sosial dalam kehidupan bermasyarakat. Tindakan rehabilitasi ditujukan kepada pelaku penyalahguna narkotika dan pecandu narkotika untuk dapat memulihkan serta mengembangkan kemampuan mental, fisik, dan sosialnya bagi penderita yang bersangkutan tersebut.

Presepsi dan kesepakatan mengenai adanya rehabilitasi ini didukung juga dengan adanya "(SEMA) Nomor 04 Tahun 2010 tentang Penempatan Penyalahgunaan, Korban Penyalahgunaan Dan Pecandu Narkotika Ke Dalam Lembaga Rehabilitasi Medis Dan Rehabilitasi Sosial”. SEMA ini merupakan wujud dari implementasi dari "Undang-Undang Narkotika" dalam Pasal 4 Huruf D yang berbunyi:

"Menjamin Pengaturan Upaya Rehabilitasi Medis dan Rehabilitasi Sosial Bagi Penyalahguna dan Pecandu Narkotika".

Serta Pasal 54 Undang-Undang Narkotika Nomor 35 Tahun 2009 Tentang Narkotika yang berbunyi:

"Pecandu Narkotika dan Korban Penyalahgunaan Narkotika Wajib Menjalani Rehabilitasi Medis dan Rehabilitasi Sosial.”

Korban Penyalahguna Narkotika menurut "Peraturan Pemerintah Nomor 25 Tahun 2011 tentang Pelaksanaan Wajib Lapor Pecandu Narkotika" adalah seseorang yang dengan sengaja menggunakan Narkotika karena dipaksa, dibujuk, diperdaya, atau bahkan diancam untuk memakai Narkotika degn tidak sengaja." Pada saat ini 
jumlah penyalahgunaan Narkotika sudah mencapai angka lebih dari 5 juta jiwa. ${ }^{9)} \mathrm{Hal}$ tersebut sebenarnya terkait dengan penjatuhkan pemidanaannya maksudnya adalah apakah seharusnya pemidanaan yang dijatuhkan kepada penyalahguna narkotika hanyalah pidana penjara saja ataukah seharusnya rehabilitasi saja. Namun pada fakta empirisnya terkait dengan rehabilitasi ini masih terjadi suatu inkonsistensi pada putusan yang dijatuhkan oleh Hakim.

Seperti kasus yang akan dijelaskan oleh penulis dimana terdapat perbedaan antara putusan satu dengan putusan yang lain dengan dijadikan sebagai pembanding. Pada kasus pertama dengan putusn nomor 375/Pid.Sus/2015/PN.JKT.Sel. dengan terdakwa bernama A.M. ENDIK ANGESTI, yang berawal dari informasi di masyarakat yang memberitahu bahwa rumah kontrakan terdakwa sering digunakan sebagai tempat penyalahgunaan narkotika kemudian anggota Sat Narkoba Polres Metro Jakarta Selatan yaitu saksi Hendi Apriadi dan Eka Hadi Ismil menuju tempat tersebut kemudian menemukan terdakwa sedang tertidur lalu kedua saksi Sat Narkoba membangunkan terdakwa dan mengintrogasi terdakwa lalu terdakwa mengakui bahwa terdakwa menyimpan Narkotika Jenis Shabu tersebut, dan ditemukannya barang bukti berupa :

- 2 (dua) pakt narkotika jenis shabu seberat 0,2407 gram;

- 3 (tiga) bungkus plastik klip bening kosong;

- cangklong, bong, dan 2 (dua) buah korek api gas;

Terdakwa membeli narkotika jenis shabu dengan harga $\mathrm{Rp} 1.000 .000$,- dari seorang bernama BUDI (DPO) di daerah Cengkareng, Jakarta Barat kemudian terdakwa mengaku bahwa terakhir kali terdakwa mengkonsumsi narkotika pada tanggal 3 Februari 2015. Berdasarkan dakwaan tersebut terdakwa dijatuhi hukuman pidana penjara selama 11 (sebelas) bulan karena melanggar unsur-unsur dalam "Pasal

9) Diskusi Kamar Pidana MA tanggal 20 Agustus 2013 : "Sosialisasi dan Diskusi Dekriminalisasi Depenalisasi dan Diversi bagi Pecandu dan korban Penyalahgunaan Narkotika". (On-Line) tersedia dhttp://www.hukumonline.com/berita/baca/lt52136123848fc/ paradigm-hakim-perkara-narkotikabelum-berubah; (diunduh tanggal 4 November 2015) 
127 Ayat (1) Undang-Undang Nomor 35 Tahun 2009 tentang Narkotika" yang diancam dengan pidana penjara paling lama 4 (empat) tahun;

Namun dalam putusan terhadap terdakwa tersebut hakim tidak menjatuhkan sanksi berupa rehabilitasi sosial dan rehabilitasi medis yang dimana seharusnya hal tersebut diwajibkan bagi pelaku penyalahguna narkotika. Sebagaimana yang telah disebutkan dalam "Pasal 127 ayat (3) bahwa jika pasal 127 ayat (1)" terbukti secara sah maka wajib melakukan rehabilitasi medis dan rehabilitasi sosial. Sedangkan jika dilihat dari kasus pada putusan 191/Pid.Sus/2015/PN.Jkt.Sel atas nama Terdakwa DARWIN TANADY als DARWIN dimana Terdakwa terdapati menyalahgunakan Narkotika jenis Shabu seberat 0,97 gram bahwa atas perbuatannya tersebut yang melanggar Pasal 127 Ayat (1) Undang-Undang Nomor 35 Tahun 2009 tentang Narkotika terdakwa dijatuhi sanksi pidana penjara selama 1 (satu) tahun dan di dalam salah satu amar putusan pengadilannya berisi “ Menetapkan agar Terdakwa tersebut menjalani Rehabilitasi di Pusat Rehabilitasi Fountain Foundation \& Institute yang beralamat di Jl. Aria Putra 73 No. 9A Kedaung Ciputat Tangerang;". Dan juga jika dilihat dalam putusan Nomor 436/Pid.Sus/2015/PN.Jkt.Sel., atas nama terdakwa DESNAL UPATI dimana Terdakwa menyalahgunakan Narkotika jenis Shabu untuk diri sendiri dengan berat 0,87 gram bahwa atas perbuatannya tersebut Terdakwa melanggar "Pasal 127 Ayat (1) Undang-Undang Nomor 35 Tahun 2009 tentang Narkotika kemudian Terdakwa dijatuhi sanksi pidana penjara selama 2 (dua) tahun 6 (enam) bulan dan menyatakan terdakwa tetap berada di dalam tahanan.

\section{B. Perumusan Masalah}

Berdasarkan latar belakang di atas, maka perumusan masalah dalam penelitian ini adalah:

1. Bagaimana penjatuhan tindakan rehabilitasi menurut Undang-Undang Nomor 35 Tahun 2009 Tentang Narkotika terhadap penyalahguna Narkotika? 
2. Mengapa terjadi perbedaan penjatuhan sanksi dalam kasus Putusan Nomor 375/Pid.Sus/2015/PN.JKT.Sel., Putusan Nomor 191/Pid.Sus/2015/PN.Jkt.Sel., Putusan Nomor 436/Pid.Sus/2015/PN.Jkt.Sel?

\section{Metode Penelitian}

Pengertian metode, berasal dari bahasa Yunani yaitu "methodos" yang diartikan cara atau menuju suatu jalan. Metode di dalam buku karangan Soejono Soekanto merupakan "suatu unsur mutlak yang harus ada dalam suatu penetilitan yang berfungsi untuk mengembangkan ilmu pengetahuan”. ${ }^{10)}$ Pengumpulan untuk mencari bahan-bahan, fakta-fakta dan juga data yang diperlukan untuk penelitian ini dengan menggunakan metode sebagai berikut:

1. Jenis Penelitian

Jenis dalam penelitian hukum terbagi menjadi 2 (dua) bagian yaitu diantaranya ialah penelitian hukum normative dan penelitian hukum empiris (sosiologi). Penelitian hukum yang digunakan dalam penulisan ini yaitu penelitian hukum normative, yang mencakup penelitian terhadap asas-asas dalam hukum.

A. Tipe Penelitian

Jenis penelitian yang digunakan berupa Penelitian Hukum Normative, yang berarti adalah "penelitian bangunan sistem norma". ${ }^{11)}$ Sistem norma yang dimaksud tersebut ialah mengenai asas dalam hukum, norma hukum, kaidh dari peraturan perundangundangan, serta putusan pengadilan.

B. Jenis Pendekatan

Menurut Mukti Fajar, jenis pendekatan dalam penelitian hukum normatif terdapat 7 pendekatan yang diantaranya adalah,

\footnotetext{
10) Soerjono Soekanto, Pengantar Penelitian Hukum, (Jakarta:UI Press, 1983), hal.7

11) Mukti Fajar ND dan Yulianto Achmad, Dualisme Penelitian Humum Normatif dan Empiris, Cetakan Ke-1 (Yogyakarta: Pustaka Belajar, 2010), hal. 34.
} 
Pendekatan Perundang-Undangan, Pendekatan Konsep, Pendekatan Analitis, Pendekatan Perbandingan, Pendekatan Sejarah, dan Pendekatan Kasus. ${ }^{12)}$ Jenis pendekatan ini adalah pendekatan Perundang-Undangan yaitu peneliti menggunakan peraturan perundang-undangan sebagai dasar awal untuk melakukan analisis.

2. Sifat Penelitian

Sifat dalam penulisan ini bersifat deskriptif analitis yang memiliki tujuan untuk memaparkan atau memperoleh tentang gambaran (deskripsi) keadaan bagaimana hukum yang berlaku di suatu tempat tertentu dan pada suatu waktu tertentu atau dapat menjelaskan mengenai gejala yuridis yang terjadi dalam masyarakat. ${ }^{13)}$ Penelitian tsb diharapkan dapat memberikan informasi secara lengkap dan jelas mengenai penjatuhan tindakan rehabilitasi terhadap pelaku penyalahguna narkotika yang terdapat dalam "Undang-Undang Nomor 35 Tahun 2009 Tentang Narkotika", "Peraturan Pemerintah Nomor 25 Tahun 2011 Tentang Pelaksanaan Wajib Lapor Pecandu Narkotika", "Surat Edaran Mahkamah Agung (SEMA) Nomor 04 Tahun 2010 Tentang Penempatan Penyalahguna, Korban Penyalahguna Dan Pecandu Narkotika Ke Dalam Lembaga Rehabilitasi Medis Dan Rehabilitasi Sosial", Putusan Nomor 375/Pid.Sus/2015/PN.JKT.Sel., Putusan Nomor 191/Pid.Sus/2015/PN.Jkt.Sel., Putusan Nomor 436/Pid.Sus/2015/ PN.Jkt.Sel."

3. Jenis dan Sumber Data

Di dalam suatu penelitian sering diperlukan bahan/data yang dicari kemudian dikelola dan selanjutnya di analisis untuk mencari jawaban dari

12) Ibid, hal. 184-191

13) Mukti Fajar ND dan Yulianto Achmad, Op.Cit, hal. 183. 
permasalahan yang diteliti untuk dapat diajukan. Data sekunder penelitian normatif meliputi bahan-bahan hukum sebagai berikut:

a. Bahan Hukum Primer, yang berarti suatu penelitian terhadap peraturan perundangan-undangan, yurisprudensi atau keputusan pengadilan yang dapt berupa studi kasus. ${ }^{14)}$ Dalam penelitian ini bahan primer yang digunakan adalah "Undang-Undang Dasar Negara Republik Indonesia 1945”, “Undang-Undang Nomor 35 Tahun 2009 tentang Narkotika”, "Peraturan Pemerintah Nomor 25 Tahun 2011 tentang Pelaksanaan Wajib Lapor Pecandu Narkotika", serta "Surat Edaran Mahkamah Agung Nomor 04 Tahun 2010 tentang Penempatan Penyalahgunaan, Korban Penyalahgunaan Dan Pecandu Narkotika Ke Dalam Lembaga Rehabilitasi Medis Dan Rehabilitasi Sosial", Putusan Nomor 375/Pid.Sus/2015/PN.JKT.Sel., $\quad$ Putusan Nomor 191/Pid.Sus/2015/PN.Jkt.Sel., Putusan Nomor 436/Pid.Sus/2015/ PN.Jkt.Sel.

b. Bahan Hukum Sekunder, yaitu bahan hukum yang memberi suatu penjelasan terhadap bahan hukum primer, yang berupa suatu rancangan perundang-undangan, hasil penelitian, buku-buku atau teks, jurnal ilmiah, surat kabar (koran), pamphlet, letleat, brosur, dan berita internet. ${ }^{15)}$

c. Bahan Hukum Tersier, yaitu bahan hokum yang memberikan petunjuk maupun penjelasan terhadap bahan hukum primer dan bahan hukum sekunder, contohnya seperti kamus hukum. ${ }^{16)}$

\section{Teknik Pengumpulan Data}

\footnotetext{
14) Mukti Fajar ND dan Yulianto Achmad, Op.cit, hal. 157.

15) Mukti Fajar ND dan Yulianto Achmad, Op.Cit, hal. 158.

16) Mukti Fajar ND dan Yulianto Achmad, Op.Cit, hal. 158.
} 
Teknik pengumpulan data yang penulis gunakan dalam penulisan ini ialah dilakukan dengan suatu penelitian studi pustaka terhadap bahan hukum primair, bahan hukum sekunder, maupn bahan hukum tersier.

5. Teknik Analisa Data

Analisis data adalah suatu kegiatan penelitian berupa dengan dilakukannya kajian atau telaah terhadap hasil pengolahan data dengan dibantu suatu teori yang telah didapatkan sebelumnya. Teknik analisis data yang digunakan adalah analiss normative kualitatif. ${ }^{17}$

\section{PEMBAHASAN}

\section{A. Analisis Mengenai Penjatuhan Tindakan Rehabilitasi Menurut Undang- Undang Nomor 35 Tahun 2009 Tentang Narkotika}

Kasus penyalahgunaan narkotika ini ialah suatu kasus yag sangat rentan untuk terjadi, ini telah terbukti dengan sering terjadinya seseorang yang positif setelah menggunakan narkotika tanpa mengetahui hal yang dilakukannya tersebut akan memasukan dirinya ke penjara. Hal ini membuktikan bahwa kasus narkotika semakin meningkat dan sulit untuk dapat diberantas dan dikurangi.

Salah satu hal tersebut dapat terjadi karena pihak aparat penegak hokum mengutamakan lebih tindakan hukum karena sangat sulit menentukan seseorang sebagai penyalahguna narkotika ataukah sebagai pengedar narkotika. Dalam hal ini justru terjadi perbandingan terbalik terhadap program yang dibuat oleh Presiden Republik Indonesia Presiden Jokowi yaitu Gerakan Rehabilitasi Penyalahguna Narkotika yang menginginkan bagi para penyalahguna narkotika agar dapat dilakukan rehabilitasi dengan dibentukan suatu Peraturan Bersama 7 Kementerian sebagai langkah untuk memberantas

17) Ronny Hanitijo Soemitro, Metode Penelitian Hukum dan Yurumetri, (Jakarta: Ghalia Indonesia, 1988), hal.11. 
dan mengurangi adanya kecanduan dan penggunaan narkotika dalam masyarakat.

Bagi seorang penyalahguna narkotika dapat dikenakan suatu tindakan rehabilitasi yang diatur dalam "Undang-Undang Nomor 35 Tahun 2009 Tentang Narkotika dalam Pasal 54, Pasal 55, Pasal 103 serta Pasal 127 kemudian juga terdapat di dalam Peraturan Bersama Para Menteri dan Surat Edaran Mahkamah Agung Nomor 04 Tahun 2010 tentang Penempatan Penyalahguna, Korban Penyalahguna Dan Pecandu Narkotika Ke Dalam Lembaga Rehabilitasi Medis Dan Rehabilitasi Sosial.”

Pertama-tama, pelaku tindak pidana tersebut adalah sebagai pengguna bukan sebagai pengedar sesuai dengan ketentuan dalam "Pasal 127 UndangUndang Nomor 35 Tahun 2009 tentang Narkotika", yang menggunakan narkotika bagi dirinya sendiri tentu saja berhak untuk di rehabilitasi dan juga menurut assesmen terpadu yang beranggotakan dari tim medis, tim sosial serta tim hukum. Kemudian, tim assesmen tersebut akan meneliti apakah penyalahguna itu mengalami ketergantungan karena bisa saja seorang penyalahguna ini tidak mengalami ketergantungan tidak perlu untuk dilakukan rehabilitasi yang akan direkomendasikan dari tim assesmen terutama dari tim medis tersebut. ${ }^{18)}$

Adapun salah satu tujuan dari "Undang-Undang Narkotika Nomor 35 Tahun 2009” yang terdapat dalam Pasal 4 yaitu:

Menjamin pengaturan upaya rehabilitasi medis dan sosial bagi Penyalah Guna dan pecandu Narkotika.

Pasal 54

"Pecandu Narkotika dan korban penyalahgunaan Narkotika wajib menjalani rehabilitasi medis dan rehabilitasi sosial."

Pasal 127

(1) "Setiap Penyalah Guna:

${ }^{18)}$ Peneliti, Wawancara, dengan Hakim Pengadilan Negeri Jakarta Selatan, (Jakarta: Pengadilan Negeri Jakarta Selatan, 16 Mei 2019). 
a. Narkotika Golongan I bagi diri sendiri dipidana dengan pidana penjara paling lama 4 (empat) tahun;

b. Narkotika Golongan II bagi diri sendiri dipidana dengan pidana penjara paling lama 2 (dua) tahun; dan

c. Narkotika Golongan III bagi diri sendiri dipidana dengan pidana penjara paling lama 1 (satu) tahun."

(2) "Dalam memutus perkara sebagaimana dimaksud pada ayat (1), hakim wajib memperhatikan ketentuan sebagaimana dimaksud dalam Pasal 54, Pasal 55, dan Pasal 103".

(3) "Dalam hal Penyalah Guna sebagaimana dimaksud pada ayat (1) dapat dibuktikan atau terbukti sebagai korban penyalahgunaan Narkotika, Penyalah Guna tersebut wajib menjalani rehabilitasi medis dan rehabilitasi sosial."

Pelaku tindak pidana yang dikategorikan sebagai pengguna bukan sebagai pengedar sesuai dengan ketentuan dalam "Pasal 127 Undang-Undang Nomor 35 Tahun 2009 tentang Narkotika”, yang menggunakan narkotika bagi dirinya sendiri tentu saja berhak untuk di rehabilitasi dan juga menurut assesmen terpadu yang beranggotakan dari tim medis, tim sosial serta tim hukum. Kemudian, dari tim assesmen tersebut akan meneliti apakah penyalahguna tersebut mengalami ketergantungan karena bisa saja seorang penyalahguna ini tidak mengalami ketergantungan tidak perlu untuk dilakukan rehabilitasi yang akan direkomendasikan dari tim assesmen terutama dari tim medis tersebut.

Tujuan pidana yang lain adalah rehabilitasi. Artinya, pelaku kejahatan harus diperbaiki kearah yang lebih baik, agar ketika kembali ke masyarakat dan tidak lagi mengulangi perbuatan jahat. Sebenarnya tujuan pidana sebagai bukanlah hal yang baru. Menurut Thomas Aquinas "dari sudut pandang Katolik sudah memisahkan antara poenae ut poenae (pidana sebagai pidana) dengan poenae ut medicine (pidana sebagai obat) dan negara menjatuhkan pidana dengan daya kerja pengobatan, maka perlu diberikan perhatian terhadap prevensi umum dan prevensi khusus (poenae praesentis vitae magis sunt medicinales quam retributative)." Dalam buku karangan Eddy O.S Hiarjie mengatakan "teori rehabilitasi juga tidak terlepas dari teori relatif yang 
berkaitan dengan prevensi." Pidana sebagai obat yang dikemukakan oleh Aquinas adalah dalam rangka memperbaiki terpidana agar ketika kembali ke dalam masyarakat tidak lagi mengulangi perbuatannya sebagaimana tujuan prevensi khusus. ${ }^{19)}$

Korban Penyalahgunaan Narkotika dan Pecandu Narkotika yang sedang menjalani suatu proses penyidikan, penuntutan, dan persidangan di pengadilan yang tanpa hak dan melawan hukum dan masih berstatus sebagai Tersangka dan/atau Terdakwa dalam penyalahgunaan Narkotika agar diberikan perawatan dan pemulihan dalam lembaga rehabilitasi. Adapun tahap-tahap rehabilitasi bagi pecandu narkoba: ${ }^{20)}$

A. "Tahap rehabilitasi medis (detoksifikasi), pada tahap ini dokter harus memiliki suatu pengalaman dan juga keahlihan untuk dapat mendeteksi gejala kecanduan terhadp pecandu narkotika untuk menentukan apakah pecandu tsb dapat diberikan obat tertentu agar dapat mengurangi gejala sakau yang di deritanya;

B. Tahap rehabilitasi nonmedis, dalam tahap ini penyalah guna mengikuti program rehabilitasi. Penyalah guna akan ditempatkan pada Rumah Sakit Ketergantungan Obat (RSKO) yang sudah tersedia di Indonesia sesuai dengan wilayah dari pecandu tsb. Di tempat rehabilitasi ini, penyalahguna narkotika menjalani program therapeutic communities (TC), 12 steps (dua belas langkah), dan lainnya;

C. Tahap bina lanjut (after care), pada tahap ini pecandu akan diberikan kegiatan yang sesuai dengn karakter serta kepribadiannya agar dapat melakukan kegiatan setiap harinya, agar pecandu daat kembali ke

19) Eddy O.S Hiarjie, Prinsip-Prinsip Hukum Pidana, (Yogyakarta: Cahaya Atma Pustaka, 2014), hal. 43

${ }^{20)}$ Badan Narkotika Nasional, Panduan Pelaksanaan Terapi Dan Rehabilitasi Berbasis Masyarakat, 2008, Badan Narkotika Nasional Republik Indonesia. 
dalam sekolah ataupun tempat kerja akan tetap berada di bawah pengawasn."

Bahwa rehabilitasi itu dijatuhkan kepada seseorang yang dikategorikan sebagai pemakai dan menggunakan narkotika yang dianggap sebagai pelaku tetapi dianggap juga sebagai korban karena orang tersebut memakai narkotika untuk diri sendiri dan merusak dirinya sendiri dengan menggunakan narkotika. Sehingga ada istilahnya decreminalisasi. Pada dasarnya "Peraturan Bersama serta (SEMA) Nomor 04 Tahun 2010" tersebut ialah peraturan perundang-undangan yang menjadi dasar agar syarat-syarat seorang penyalahguna dapat dilakukan upaya rehabilitasi, namun untuk menyatakan apakah seorang pelaku tindak pidana tersebut sebagai pengedar ataukah sebagai penyalahguna narkotika tetap melihat kepada "Undang-Undang Nomor 35 Tahun 2009 tentang Narkotika.”

B. Analisis Penjatuhan Tindakan Rehabilitasi Terhadap Pelaku Tindak Pidana Penyalahgunaan Narkotika dalam Putusan Pengadilan Negeri Jakarta Selatan Nomor 375/Pid.Sus/2015/PN.Jkt.Sel, Putusan Pengadilan Negeri Jakarta Selatan Nomor 191/Pid.Sus/2015/PN.Jkt.Sel, dan Putusan Pengadilan Negeri Jakarta Selatan Nomor 436/Pid.Sus/2015/PN.Jkt.Sel

Dalam penelitian ini, Penulis melakukan analisis dan perbandingan terhadap 3 (tiga) kasus penyalahgunaan narkotika yang serupa dengan 3 (tiga) putusan yang berbeda. Pertama-tama dalam Putusan Pengadilan Negeri Jakarta Selatan Nomor 375/Pid.Sus/2015/PN.Jkt.Sel, dengan seorang yang berkonflik dengan hukum bernama A.M. Endik Angesti berumur 52 tahun.

A.M. Endik Angesti diancam dengan "Pasal 127 Ayat (1) Undang-Undang Narkotika" yang berbunyi:

"Setiap Penyalah Guna:

(1) "Narkotika Golongan I bagi diri sendiri dipidana dengan pidana penjara paling lama 4 (empat) tahun; 
(2) Narkotika Golongan II bagi diri sendiri dipidana dengan pidana penjara paling lama 2 (dua) tahun; dan

(3) Narkotika Golongan III bagi diri sendiri dipidana dengan pidana penjara paling lama 1 (satu) tahun."

Dalam hal ini, Ketua Pengadilan Negeri Jakarta Selatan memutus agar Terdakwa diberikan hukuman pidana penjara selama 11 (sebelas) bulan dan memerintahkan agar terdakwa tetap berada di dalam penjara.

Kemudian, dalam Putusan Pengadilan Negeri Putusan Pengadilan Negeri Jakarta Selatan Nomor 191/Pid.Sus/2015/PN.Jkt.Sel atas nama Terdakwa DARWIN TANADY als DARWIN yang berumur 34 Tahun, pada hari Sabtu tanggal 13 Desember 2014 sekira jam 14.00 WIB atau setidak-tidaknya pada waktu ini masih termasuk bulan Desember 2014, yang beralamat di Apartemen Season City, Kelurahan Tambora, Kecamatan Tambora Jakarta Barat dan berdasarkan "Pasal 84 ayat (2) KUHAP" karena terdakwa ditahan dan sebagian saksi yang dipanggil lebih dekat ke Pengadilan Negeri Jakarta Selatan atau setidak-tidaknya Pengadilan Negeri Jakarta Selatan yang berhak mengadili dan memeriksa perkara ini, penyalah guna Narkotika Golongan I bagi diri sendiri. Selanjutnya anggota Kepolisian Polres Metro Jakarta Selatan melakukan penangkapan dan penggeledahan di tempat kediaman Terdakwa Darwin Tanady, ketika dilakukan hal tersebut terdakwa Darwin Tanady kedapatan menyimpan 1 (satu) buah plastik bening transparan yag berisikan narkotika jenis shabu dengan berat brutto 0,97 gr yang berada di dalam rak TV di dalam kamar Apartemen milik terdakwa Darwin Tanady, yang menurut terdakwa bahwa barang shabu tersebut di dapat dengan membeli kepada seorang yang bernama Yorin dengan harga sebesar Rp 2.000.000,- (dua juta rupiah).

Bahwa terdakwa Darwin Tanady menggunakan narkotika jenis shabu sudah selama 4 (empat) tahun, dikarenakan dengan alasan bahwa terdakwa memiliki banyak pikiran dan susah untuk tidur. Terdakwa telah mencoba untuk berobat di Negara Singapore untuk menghilangkan ketergantungan namun malah membuat terdakwa menjadi semakin tidak membaik atau membuat terdakwa linglung. Berdasarkan 
dengan uraian diatas maka terdakwa Darwin Sanady melakukan penyalahguna narkotika bagi dirinya sendiri, sebagaimana diatur dan diancam pidana dalam "Pasal 127 Ayat (1) Undang-Undang Narkotika Nomor 35 Tahun 2009.”

Selanjutnya, dalam Putusan Pengadilan Negeri Jakarta Selatan Nomor 436/Pid.Sus/2015/PN.Jkt.Sel., atas nama terdakwa DESNAL UPATI yang berumur 20 tahun. Dengan posisi kasus dalam perkara pada pokoknya adalah sebagai berikut: Bahwa ia terdakwa DESNAL UPATI, pada hari Rabu tanggal 18 Februari 2015 sekira pukul 21.30 WIB, atau setidak-tidaknya pada waktu lain dalam bulan Februari tahun 2015 bertempat di JI. Menteng Rawa Panjang Gg. Karya II RT. 008/007 Kel. Menteng Atas Kec. Setiabudi Jakarta Selatan, atau setidak-tidaknya disuatu tempat yang masih termasuk dalam wilayah hukum Pengadilan Negeri Jakarta Selatan, tanpa hak atau melawan hukum, Menggunakan Narkotika Golongan I Diri Sendiri.

Berawal dari adanya informasi dari masyarakat di JI. Menteng Rawa Panjang Gg. Karya II RT. 008/007 Kel. Menteng Atas Kec. Setiabudi Jakarta Selatan sering digunakan sebagai tempat penyalahgunaan Narkotika. selanjutnya saksi Yudi Harsono, saksi Evin Susanto dan saki Teja Buana (ketiganya merupakan anggota Sat Narkoba Polsek Metro Tebet Jakarta Selatan) menuju tempat tersebut. Sesampainya di Jl. Menteng Rawa Panjang Gg. Karya II RT. 008/007 Kel. Menteng Atas Kec. Setiabudi Jakarta Selatan para saksi mendapati terdakwa DESNAL UPATI Bin Alm UMPANG yang baru tiba dirumah diminta untuk membuka pintu rumah, saat dilakukan penggeledahan terhadap badan terdakwa ditemukan barang bukti berupa 3 (tiga) bungkus plastik bening berisi shabu di dalam bekas kotak permen warna merah, 2 (dua) buah cangklong dan 2 (dua) buah bong dimeja dapur. Selanjutnya terdakwa berikut barang bukti diamankan di Kantor Polsek Metro Tebet Jakarta Selatan. Putusan hakim dalam perkara tersebut adalah menjatuhkan pidana penjara terhadap terdakwa tersebut pidana penjara selama 2 (dua) tahun 6 (enam) bulan dan memerintahkan agar terdakwa tetap berada di dalam tahanan. 
Seperti yang kita ketahui, bahwa Tindak pidana narkotika ini merupakan musuh bersama untuk bangsa ini karena narkotika dapat merusak generasi muda penerus bangsa. Dalam "Undang-Undang Nomor 35 Tahun 2009 tentang Narkotika", kalau tindak pidana yang dilakukan itu menyatakan pelaku sebagai penyalahguna narkotika bagi diri sendiri berarti pelaku tersebut adalah sebagai korban penyalahguna narkotika untuk itu undang-undang memberikan jalan atau ruang bahwa korban ini seharusnya diobati dengan menjalani rehabilitasi. Rehabilitasi ini bisa dilakukan untuk mengembalikan jiwa sosial si penyalahguna narkotika tersebut karena akibat dari ketergantungan tersebut penyalahguna narkotika mengalami linglung, tidak bisa bergaul, tidak memiliki jiwa masyarakat maka di rehabilitasi secara sosial.

Menyadari kenyataan yang demikian maka hukum harus memberikan suatu perlindungan khusus kepada pelaku penyalahguna narkotika. Hal ini direalisasikan dengan lahirnya "Undang-Undang Narkotika Nomor 35 Tahun 2009 tentang Narkotika" ditambah dengan Peraturan Perundangan-Undangan yang lain seperti yaitu "Peraturan Bersama 7 Kementerian tentang tentang Penanganan Pecandu Narkotika dan Korban Penyalahguna Narkotika Ke Dalam Lembaga Rehabilitasi dan Surat Edaran Mahkamah Agung (SEMA) Nomor 04 Tahun 2010 tentang Penempatan Penyalahguna, Korban Penyalahgunaan dan Pecandu Narkotika Ke Dalam Lembaga Rehabilitasi Medis dan Rehabilitasi Sosial.”

Berdasarkan Pasal 4 huruf d salah satu dari tujuan Undang-Undang Narkotika adalah "untuk menjamin pengaturan upaya rehabilitasi medis dan sosial bagi Penyalah Guna dan pecandu Narkotika." Dengan adanya ketentuan yang terdapat dalam pasal tersebut maka dibentuk Peraturan Bersama dan juga Surat Edara Mahkamah Agung yang mengatur tentang tindakan rehabilitasi. Dalam penulisan ini, Penulis menganalisa pelaku tindak pidana penyalahguna narkotika, maka Penulis pun melihat bagaimana upaya penyembuha dari penyalahguna yang menjadi korban penyalahgunaan narkotika. Berdasarkan "Pasal 54 Undang-Undang Narkotika, bagi 
pelaku yang menjadi korban penyalahgunaan narkotika dilakukan upaya rehabilitasi sosial dn rehabilitasi medis."

Dalam penelitian ini, Penulis meneliti tentang seorang yang melakukan tindak pidana narkotika, yaitu berupa penyalahgunaan narkotika bagi diri sendiri, dalam arti ini bahwa pelaku penyalahguna tersebut memakai narkotika tanpa hak atau melawan hukum. Hal ini selain merusak diri sendiri, juga dapat merusak lingkungan. Walaupun demikian, negara berdasarkan Undang-Undang Narkotika telah memberikan upaya penyembuhan dengan rehabilitasi dan juga pencegahan dini terhadap pelaku penyalahguna narkotika. Semua teori-teori dan peraturan-peraturan yang memberi upaya dan pencegahan bagi pelaku penyalahguna narkotika terdengar bagus di atas kertas, namun bagaimana dalam prakteknya?

Berdasarkan hasil wawancara, Hakim Pengadilan Negeri Jakarta Selatan setuju dengan adanya rehabilitasi medis dan rehabilitasi sosial dalam menangani permasalahan penyalahgunaan narkotika. Menurut Bapak Achmad, setiap kasus penggunaan narkotika bagi diri sendiri yang memenuhi syarat untuk dilakukan rehabilitasi berdasarkan "Surat Edaran Mahkamah Agung (SEMA) Nomor 04 Tahun 2010 tentang Penempatan Penyalahguna, Korban Penyalahguna Dan Pecandu Narkotika Ke Dalam Lembaga Rehabilitasi Medis Dan Rehabilitasi Sosial” akan diupayakan rehabilitas, namun jika tidak memenuhi syarat maka akan dijatuhi pemidanaan berupa pidana penjara. ${ }^{21)}$

Namun demikian, Penulis berpendapat bahwa sesuai dengan ketentuan "Pasal 127 UU Narkotika", karena pidana penjara yang dapat dijatuhkan kepada penyalahguna narkotika paling lama 4 (empat) tahun, namun tentu saja hal ini dibarengkan dengan upaya tindakan rehabilitasi medis dn rehabilitasi sosial. Jadi, pelakupenyalahguna narkotika ini mendapatkan pemidanaan dan tindakan rehabilitasi

21) Peneliti, Wawancara, dengan Hakim Pengadilan Negeri Jakarta Selatan, (Jakarta: Pengadilan Negeri Jakarta Selatan, 16 Mei 2019). 
Hal ini memberi kesan bahwa pihak-pihak yang terkait dalam menangani kasus penyalahguna narkotika belum dapat menguasai peraturan perundang-undangan yang mengatur mengenai hal tersebut, sehingga dalam menangani kasus penyalahguna narkotika itu, tidak diperhatikannya bahwa ancaman pidana yang tertera merupakan ancaman yang diterapkan dengan memperhatikan ayat selanjutnya dalam pasal terkait.

Terhadap perbedaan putusan dalam kasus-kasus penyalahguna narkotika ini, menurut Bapak Hery, bahwa Hakim itu memiliki independensi, Hakim yang mengetahui dengan berkordinasi dengan aparat penegak hukum lainnya dengan memperhatikan barang buktinya sepertinya apa, apakah pelaku tindak pidana tersebut layak untuk mendapatkan penanganan dalam rehabilitasi ataukah adanya tindakan lain. Tentunya, nanti Hakim akan menilai dan mempertimbangkan fakta hukumnya tidak dengan sembarangan menggunakan Pasal 127 tersebut. Maka, hal tersebut akan dibuktikan kebenarannya dalam persidangan. Hakim itu kan indenpendensi berarti masing-masing hakim berhak untuk memutus. Ada istilah "Res Judicata Pro Veritate Habetur" yaitu suatu asas hukum yang artinya apa yang diputus oleh hakim harus dianggap benar sampai memperoleh kekuatan hukum yang tetap atau diputus lain oleh Pengadilan yang lebih tinggi (Banding atau Kasasi). ${ }^{22)}$

Namun apabila Penulis membandingkan ketiga kasus yang diteliti, terlihat jelas bahwa terdapat suatu kejanggalan. Dari segi berat narkotika, beratnya berturut-turut (tinggi ke rendah) Putusan Nomor 436/Pid.Sus/2015/PN.Jkt.Sel seberat 0,87 gram, Putusan Nomor 191/Pid.Sus/2015/PN.Jkt.Sel seberat 0,97 gram, dan Putusan Nomor 375/Pid.Sus/2015/PN.Jkt.Sel seberat 0,2407 gram. Ketiganya merupakan penyalahguna, namun amarnya berturut-turut (tinggi ke rendah) Putusan 436/Pid.Sus/2015/PN.Jkt.Sel penjara 2 (dua) tahun 6 (enam) bulan, Putusan Nomor 191/Pid.Sus/2015/PN.Jkt.Sel penjara 1 (satu) tahun dan menjalani Rehabilitasi di

22) Peneliti, Wawancara, dengan Dosen Pidana Fakultas Hukum Universitas Tarumanagara, (Jakarta: Universitas Tarumanagara, 13 Mei 2019). 
Pusat Rehabilitasi Fountain Foundation \& Institute di Ciputat Tangeran dan Putusan Nomor 375/Pid.Sus/2015/PN.Jkt.Sel penjara 11 (sebelas) bulan.

Walaupun Penulis setuju dengan pendapat Bapak Hery yang mengatakan bahwa hakim memiliki indepedensi, sehingga perkara yang satu tidak bisa secara serta merta disamakan dengan perkara yang lain, namun setelah melakukan penelitian dan perbandingan, terlihat jelas bahwa dalam hal ini kasus-kasus yang diteliti memiliki fakta-fakta hukum yang serupa, sehingga perbedaan penerapan hukum yang begitu signifikan terasa seakan-akan mengabaikan prinsip dasar penyelenggaraan upaya memberentas narkotika dari pemakaian narkotika di Indonesia. Dalam menjatuhakan pidana bagi penyalahguna narkotika ini bukan dengan semata-semata untuk pembalasan tetapi harus benar-benar mempertimbangkan penyembuhan dari pemakaian narkotika tersebut agar tidak melakukan untuk memakai narkotika kembali. ${ }^{23)}$ Penulis berpendapat bahwa dalam kasus penyalahguna narkotika bagi diri sendiri, pelaku penyalahguna narkotika memiliki hak-hak yang harus dipenuhi. Dimulai hak untuk diupayakan rehabilitasi medis dan rehabilitasi sosial, hak untuk mendapatkan pengobatan sesuai dengan prosedur yang sesuai dengan program pemerintah dan ketentuan dalam Peraturan Perundang-Undangan.

\section{PENUTUP}

\section{A. Kesimpulan}

Berdasarkan penelitian yang telah dilakukan, Penulis menyimpulkan dalam bab ini sebagai berikut:

1. Berdasarkan pada apa yang telah tertulis dalam ketentuan "Undang-Undang Narkotika" tersebut mewajibkan agar penyalahguna narkotika serta pecandu narkotika untuk menjalani rehabilitasi medis dan rehabilitasi sosial yang tertuang di dalam Pasal 4, Pasal 54, Pasal 127 Ayat (3) dengan ketentuan atau syarat yang terdapat dalam "Surat Edaran Mahkamah Agung (SEMA)

23) Peneliti, Wawancara, dengan Dosen Pidana Fakultas Hukum Universitas Tarumanagara, (Jakarta: Universitas Tarumanagara, 13 Mei 2019). 
Nomor 04 Tahun 2010”. Pelaksanaan rehabilitasi menurut peraturan yang berlaku terhadap penyalahguna narkotika masih belum diterapkan secara baik oleh aparat penegak hukum karena dalam praktiknya cara masingmasing aparat penegak hukum memiliki perbedaan untuk menerapkan hukum tersebut.

2. Berdasarkan penelitian yang telah dilakukan, Penulis menyimpulkan bahwa perbedaan antara putusan pengadilan terhadap penyalahguna narkotika dalam Putusan Pengadilan Negeri Jakarta Selatan Nomor 375/Pid.Sus/2015/PN.JkT.Sel., Putusan Pengadilan Negeri Jakarta Selatan Nomor 191/Pid.Sus/2015/PN.Jkt.Sel., dan Putusan Pengadilan Negeri Jakarta Selatan Nomor 436/Pid.Sus/2015/PN.Jkt.Sel., diakibatkan oleh halhal sebagai berikut:

a. Adanya suatu inkonsistensi antara peraturan perundang-undangan yang mengatur mengenai rehabilitasi. Perbenturan atau perbedaan tersebut terjadi antara peraturan perundang-undangan yaitu UndangUndang Narkotika, SEMA Nomor 04 Tahun 2010 serta Peraturan Bersama 7 Kementerian yang menimbulkan kebingungan bagi aparat penegak hukum. Undang-Undang Narkotika dalam pasal tertentu yang membahas rehabilitasi mewajibkan dengan melihat ketentuan atau syarat-syarat dalam "SEMA Nomor 04 Tahun 2010" namun dalam prakteknya terjadi inkonsistensi, sehingga bagi pelaku penyalahguna narkotika dapat diupayakan rehabilitasi, ada juga yang tidak;

b. Hakim memiliki indepedensi atau kebebasan dalam memutus perkara. Hakim di Indonesia dalam memutus perkara tsb tidak ada kewajiban untuk mengikuti suatu putusan terdahulu karena setiap hakim memiliki kepercayaan/keyakinan sendiri dalam memutus suatu perkara. 
c. Suatu peraturan yang berlaku terhadap tindak pidana tertentu tidak selalu diterapkan oleh para instansi terkait karena dalam prakteknya para instansi tersebut mempunyai cara pandang dan berfikir masingmasing sehingga peraturan yang telah dibentuk tidak selalu sama untuk diterapkan.

\section{B. Saran}

Bagi masyarakat agar menghindar dan menjauhi perbuatan pidana seperti memakai dan menggunakan narkotika jenis apapun agar tidak mempengaruhi perkembangan fisik, mental, dan rohaninya secara negatif akibat terjadinya ketergantungan. Oleh karena itu, walaupun pelaku penyalahguna narkotika melakukan penyimpangan dan melawan hukum Negara harus tetap memberikan perlindungan terhadapnya. Perlindungan tersebut terdapat dalam UndangUndang Narkotika yang secara mutlak harus diterapkan bagi pelaku penyalahguna narkotika.

Bagi hakim, penyidik, dan jaksa penuntut umum sebagai aparat penegak hukum harus memperhatikan hak-hak dari korban penyalahguna narkotika untuk mendapatkan kesembuhan dengan menjalankan rehabilitasi medis dan rehabilitasi sosial atas rekomendsi assesmen terpadu dai tim medis.

Pemerintah harus secara tegas melakukan sosialisasi "Undang-Undang Nomor 35 Tahun 2009 tentang Narkotika", sehingga dapt meningkatkan efektivitas Badan Narkotika Nasional (BNN), serta dapat melakukan penanggulangan dari penyalahgunaan Narkotika dengan memberikan kesadaran hukum bagi masyarakat di Indonesia.

\section{DAFTAR PUSTAKA}

\section{A. Buku}

Adi, Kusno. Kebijakan Kriminal Dalam Penanggulangan Tindak Pidana Narkotika Oleh Anak. Cetakan Ke-1. Malang: UMM Press, 2009.

Fajar, Mukti ND dan Yulianto Achmad, Dualisme Penelitian Humum Normatif dan Empiris. Cetakan Ke-1. Yogyakarta: Pustaka Belajar, 2010. 
Hiarjie, Eddy O.S. Prinsip-Prinsip Hukum Pidana. Yogyakarta: Cahaya Atma Pustaka, 2014.

Iskandar, Anang. Jalan Lurus Penangan Penyalahguna Narkotika Dalam Konstruksi Hukum Positif. Karawang: Viva Tanpas, 2015.

Makaro, Moh Taufik. Dkk. Tindak Pidana Narkoba. Bogor: Penerbit Ghalia Indonesia, 2005.

Moeljatno. Asas-Asas Hukum Pidana,Edisi Revisi. Jakarta: Rineka Cipta, 2008.

Setiady, Tolib. Pokok-Pokok Hukum Penitensier Indonesia. Bandung: Alfabeta, 2010.

Soekanto, Soekanto. Pengantar Penelitian Hukum. Jakarta:UI Press, 1983.

Winarta, Frans Hendra. Bantuan Hukum: Suatu Hak Asasi Manusia Bukan Belas Kasihan. Jakarta: PT. Elex Media Komputindo, 2000.

\section{B. Artikel Jurnal Cetak}

Prianto, Yuwono. "Penyalahgunaan Narkoba dan Upaya Penegakan Hukumnya", Jurnal Era Hukum Ilmiah Ilmu Hukum. Edisi No. 1 Tahun 2015.

\section{Website}

Diskusi Kamar Pidana MA tanggal 20 Agustus 2013 : "Sosialisasi dan Diskusi Dekriminalisasi Depenalisasi dan Diversi bagi Pecandu dan korban Penyalahgunaan Narkotika". (On-Line) tersedia dhttp://www.hukumonline.com/berita/baca/lt52136123848fc/ paradigm-hakim-perkara-narkotika-belum-berubah; (diunduh tanggal 4 November 2015) 